\title{
Effect of Brine fermented Pickling to Physicochemical, Anti-nutritional, and Microbiological Attributes of Pickled gboma Eggplant (Solanum macrocarpon)
}

\section{Nguyen Phuoc Minh $\mathbb{C}$}

Institute of Applied Technology, Thu Dau Mot University, Binh Duong Province, Vietnam.

\footnotetext{
*Correspondence: nguyenphuocminh@tdmu.edu.vn
}

(Received: July 5, 2021; accepted: October 25, 2021)

Citation: Minh NP. Effect of Brine fermented Pickling to Physicochemical, Anti-nutritional, and Microbiological Attributes of Pickled gboma Eggplant (Solanum macrocarpon). J Pure Appl Microbiol. 2022;16(1):263-275. doi: 10.22207/JPAM.16.1.15

(C) The Author(s) 2022. Open Access. This article is distributed under the terms of the Creative Commons Attribution 4.0 International License which permits unrestricted use, sharing, distribution, and reproduction in any medium, provided you give appropriate credit to the original author(s) and the source, provide a link to the Creative Commons license, and indicate if changes were made. 


\begin{abstract}
Gboma eggplant (Solanum macrocarpon) has low calorie, high phenolic and antioxidant, excellent dietary fibre and mineral content. Besides healthy effects, gboma eggplant also contained numerous anti-nutrients unbeneficial for human health. Due to high moisture content, gboma eggplant was highly perishable during post-harvest. This research observed the changes of nutritional proximate, mineral contents, acidification indexes, anti-nutrients, phytochemical and antioxidant properties, texture profiles, microbiological characteristics of both raw and pickled gboma eggplant. Gboma eggplant fruits were soaked in clean water for $\mathbf{2}$ minutes before cutting their calyx lobes. The pre-treated fruits were submerged in sterilized brine ( $5 \%$ salt) for 8 days. Periodically, pickled samples were taken to examine physicochemical, anti-nutritional, and microbiological attributes of pickled gboma eggplant. Results showed that nutritional proximate of moisture, ash, protein, fat, fibre, carbohydrate was varied slightly during fermentation. There was a decreasing trend of moisture and carbohydrate; meanwhile, there was an increasing trend of ash, protein, fibre during 8 days of fermentation. There was no significant difference of fat during pickling. There was a minor increment of mineral contents in all samples. There was accumulation of phenyllactic acid, ascorbic acid content and titratable acidity with exception of pH. Anti-nutrient contents like tannin, phytate, oxalate, steroidal glycoalkaloid greatly decreased in raw and pickled eggplant. Remarkable increments of total phenolic, flavonoid, DPPH free radical scavenging and FRAP ferric reducing antioxidant of raw and pickled eggplant was presented. Texture profiles of hardness, crispness, fracturability, crunchiness revealed a minor reduction of sensory scores during 8 days of fermentation. Lactic acid bacteria, Bacillus significantly proliferated; meanwhile, Micrococcus and $S$. aureus were absolutely retarded in pickled eggplant. Yeast and fungi increased in the first 4 days and decreased afterwards. There was no significant difference of proximate compositions; mineral contents; phenyllactic acid, ascorbic acid content, $\mathrm{pH}$ and titratable acidity; anti-nutritional contents; phytochemical and antioxidant properties; texture profile (sensory score); microbiological load (with exception of $S$. aureus) between pickled gloma eggplants at day $6^{\text {th }}$ and day $8^{\text {th }}$ of fermentation. At a quick glance, the length of fermentation could be shorted to 6 days instead of 8 days. However, at the $6^{\text {th }}$ day, $S$. aureus load was still presented at $0.33 \pm 0.01 \mathrm{log}$ CFU/g. The fermentation should be lasted to $8^{\text {th }}$ day so that $S$. aureus load could be dropped down to zero to ensure microbial food safety. Raw gboma eggplant should be fermented in $8 \%$ brine solution for 8 days to obtain the best physicochemical, anti-nutritional, and microbiological properties of pickle. Findings of this research suggested that fermentation pickling would be an appropriate approach to improve nutritional, physicochemical and functional criteria while controlling toxic chemical residues, retarding the growth and proliferation of spoilage and pathogen microorganisms.
\end{abstract}

Keywords: Anti-nutrient, antioxidant, gboma eggplant, microorganism, nutritional proximate, phytochemical, pickling, texture profile

\section{INTRODUCTION}

Gboma eggplant (Solanum macrocarpon) is a common vegetable crop widely distributed in tropical and subtropical regions especially at high rainfall areas. The fruit included numerous seeds and it's partly filled by the calyx lobes. ${ }^{1}$ It could be eaten raw, boiled, fried, stewed, or sauced. Gboma eggplant could be utilized for obesity prevention as well as limitation of numerous ailments. ${ }^{2,3}$ Eggplant consisted of vitamin $C$ and phenolic substances as potent antioxidants. ${ }^{4}$ Excellent antioxidant capacity of gboma eggplant might be due to the excess amount of phenolic. ${ }^{5}$ It effectively blocked tumor development and metastasis, ${ }^{6}$ prevented inflammation, hypotensive and atherosclerosis. ${ }^{7}$
Eggplant extract had excellent healing impact on various internal and external disorders. ${ }^{8}$ It had a great potential in shooting superoxide free radicals and retardation of hydroxyl radical establishment via cross-blocking ferrous [3+]. ${ }^{6}$ Gboma eggplant with naturally fibrous skin created a defence mechanism against microbial invasion. Due to low calorie and high moisture content, gboma eggplant was very sensitive and perishable quickly under ambient conditions. Dehydration, postharvest disease and flesh browning were major quality deteriorations. Eggplant microstructure mostly included epithelial tissues. During pickling, dimension and image of the epithelial tissues were modified in the cell walls. ${ }^{9}$ 
Pickling was one of the oldest food preservation methods by either ways: (1) adding sugar for fermentation, (2) brine and or acetic acid for acidification. It involved extending shelf life of finished product under strong acidity, allowing its stability for years without freezing. ${ }^{10}$ Pickling produced the finished product with desired taste, distinctive flavour and texture for long term consumption during off season. Lactic acid bacteria with probiotic properties improve self immune to contagious ailments in the gastrointestinal rout, against urogenital contamination, powerful cancer retardation, better metabolism, and lower triglyceride index in the serum. ${ }^{11}$ Moderate consumption of pickled foodstuffs might cure muscle cramp of athletes through modification of electrolyte in plasma. ${ }^{12}$ The fermentation naturally converted sugar to acid by lactic acid bacteria. ${ }^{13}$ Brine contributed a key role in pickling by extracting moisture and substrate from plant which was available for lactic acid bacteria growth and proliferation. In order to obtain pickled products with acceptable physicochemical, anti-nutritional properties and microbial safety advantages, purpose of our study focused the changes of nutritional proximate, mineral contents, acidification indexes, anti-nutrients, phytochemical and antioxidant properties, texture profiles, microbiological characteristics of both raw and pickled gboma eggplant during 8 days of fermentation in $5 \%$ brine solution. Through pickling process, the added-value of raw gboma eggplant would be improved; consumers had more chance to use diversified food.

\section{MATERIALS AND METHODS Material}

Gboma eggplant fruits were harvested in gardens of Binh Phuoc province, Vietnam. They were moved to laboratory quickly ready for experiments. Chemical reagents such as methylene blue, acetonitrile, methylene red, sulfuric acid, ammonia solution, ascorbic acid, potassium iodide, potassium persulphate, phenolphthalein, boric acid indicator, ethanol, methanol, aluminium chloride, sodium acetate, $\mathrm{HCl}, \mathrm{FeCl}_{3} \cdot 3 \mathrm{H}_{2} \mathrm{O}$ were all analytical grade. Phenyllactic acid standard (> $98.0 \%$ purity), sodium carbonate was obtained from Fluka (Switzerland). Folin-Ciocalteu phenol, trichloro-acetic acid, DPPH (2, 2-Diphenyl picrylhydrazyl) reagent, sodium nitrite $(\geq 99.0$ $\%$ purity), gallic acid and catechin reagents were purchased from Sigma Aldrich (USA). 3M-Petrifilm plates were purchased from Van Dai Phat Co. Ltd., Ho Chi Minh city, Vietnam.

\section{Researching method}

Gboma eggplant fruits were preliminarily washed under soaking with clean water for 2 minutes to separate dirt and soil. Sharp blade was used to cut their calyx lobes. The pre-treated fruits were then submerged in sterilized brine $(5 \%$ salt) for 8 days. In 2 day-interval, samples were taken to determine nutritional proximate, mineral contents, acidification indexes, anti-nutrients, phytochemical and antioxidant properties, texture profiles, microbiological characteristics of both raw and pickled gboma eggplant.

Chemical compositions (moisture, ash, protein, fat, fibre, carbohydrate) were measured following the official method of analysis. ${ }^{14}$. Mineral compositions ( $\mathrm{Na}, \mathrm{K}, \mathrm{Ca}, \mathrm{Mg}, \mathrm{P}, \mathrm{Fe}$, $\mathrm{mg} / 100 \mathrm{~g}$ ) were determined following Pearson protocol with flame photometer ( $\mathrm{Na}, \mathrm{K}$ ) (Model: 1382, ESICO), atomic absorption spectrum (Ca, $\mathrm{Mg}, \mathrm{Fe}$ ) (model: PINAACLE900F, PerkinElmer) and spectrophotometer (P) (model UV-1800, Shimazu). Phenyllactic acid ( $\mathrm{mg} / \mathrm{g}$ ) was determined by high-performance liquid chromatography or HPLC (model: HPLC 580, Techno) with ultraviolet detection. ${ }^{15}$ Ascorbic acid content $(\mathrm{mg} / 100 \mathrm{~g})$ was measured by volumetric method using a 2,6-dichlorophenol indophenol visual titration method described by AOAC16. pH was measured with a $\mathrm{pH}$ meter (Hanna Instruments). Titratable acidity (mg lactic acid/100 g) was measured following the official method of analysis. ${ }^{14}$ Tannin $(\mathrm{mg} / \mathrm{g})$ was determined following the method described by Adegunwa et al. ${ }^{17}$ Phytate (mg/g) was measured by the method described by Wheeler and Ferrel. ${ }^{18}$ Oxalate $(\mathrm{mg} / 100 \mathrm{~g})$ was examined by the method described by Falade et al. ${ }^{19}$ Steroidal glycoalkaloid (mg solamargine/ $\mathrm{kg}$ ) was determined by HPLC method described by Eanes et al. ${ }^{20}$ (model: HPLC 580, Techno). Total phenolic content or TPC (mg GAE/100g) was estimated by Folin-Ciocalteu reagent assay. ${ }^{21}$ Aluminium chloride colorimetric method was applied for quantification of total flavonoid content or TFC (mg QE/100 g). ${ }^{22}$ DPPH free radical scavenging (mg TE/100 g) was estimated using UV-VIS 
spectrophotometric method (model: UV5, Mettler Toledo) at wavelength $517 \mathrm{~nm} .{ }^{23} \mathrm{FRAP}$ (mg TE/100 g) ferric reducing antioxidant was defined as power in reducing of $\mathrm{Fe}^{+3}$ to $\mathrm{Fe}^{+2}$ by an antioxidant using the method described by Benzie and Strain. ${ }^{24}$ Texture profiles of hardness, crispness, fracturability, crunchiness based on 15-point scale were assessed by descriptive sensory analysis using the Spectrum ${ }^{\text {TM }}$ method. ${ }^{25}$ Panelists of 9 assessors (age 30-40 years old) were previously trained (90 hours) to utilize a 15-point strength ratio to evaluate hardness, crispness, crunchiness, fracturability in pickled products. During the training, panelists were individually evaluated to determine the overall panel mean and to ensure that all panelists were able to scale the properties of interest. Panelists were trained to rate hardness, crispness, crunchiness, fracturability based on reference samples proposed by the Spectrum ${ }^{\text {TM }}$ protocol. Hardness was mentioned as the force necessary to compress the sample on first bite, with anchors between 0 (soft) and 15 (firm). Crispness was considered as the multiple, higherpitched sounds emitted as the sample was crushed with the molar teeth. Crunchiness was described as a mono lower-toned noise released with each chew. Fracturability was elaborated as the strength in which the sample ruptures when bit down on between the molar teeth at a fast rate. Following training, panelists discussed together to an agreeing mark for each attribute of the pasteurized eggplant pickles, which were prepared directly from fermented eggplants and were provided as a reference sample. Reference pickles were stored at $4^{\circ} \mathrm{C}$ throughout the experiment and maintained their texture attributes, which were determined during the initial training of the panelists. Sensory evaluation. Samples analyzed for sensory evaluation were prepared in 2 oz. plastic cups specified with casual 3 digit numbers. All samples and the neutral pickle were prepared at ambient temperature accompanied by normal temperature distilled water, a $2 \mathrm{oz}$. sample of bread, and salt-free saltine biscuits to neutralize the palate between samples. Panelists were provided samples in a ordinary order to prevent prediction based on the order of sample display. Three to five pickle pieces were set in each sample cup. Panelists examined a set of 5 to 7 samples per session. They were also offered two $2 \mathrm{oz}$. sample cups specified as the neutral sample to calibrate scoring of taste and texture characteristics on the 15-point scale. Each panelist was guided to first taste the neutral sample, neutralize panelist's palate, and bite an unidentified pickle sample. Panelists were required to relax in two-minute interval between two samples to minimize tasting tiredness. They could either swallow or expectorate their samples. Three sensory replications were executed on each sample during the research. Sensory evaluation was performed on pickle samples, which were preserved at room temperature. The sensory profiling method was used during the sensory evaluation. Lactic acid bacteria or LAB (log CFU/g), Bacillus sp. (log CFU/g), Micrococcus (log CFU/g), Staphylococcus aureus (log CFU/g), yeast (log CFU/g) and filamentous fungi (log CFU/g) were enumerated by $3 \mathrm{M}$-Petrifilm protocols.

\section{Statistical analysis}

The experiments were run in triplicate with different groups of samples. The data were presented as mean \pm standard deviation. Statistical analysis was performed by the Statgraphics Centurion version XVI. The mean value and standard deviation of a set of data obtained by analysis of random samples estimating the population statistics. $95 \%$ of results would be expected to lie within the range $\bar{x} \pm 2 s$ we described the lower and upper bounds of this range as the $95 \%$ confidence limits of the results. The differences between the pickling samples were analyzed using a one-way analysis of variance (ANOVA). A significant value was set at a $95 \%$ confidence interval $(P \leq 0.05)$. . If significant differences were found, then post hoc analysis was performed using Duncan's multiple range tests.

\section{RESULTS AND DISCUSSION}

The proximate compositions of raw and pickled gboma eggplant were presented in Table 1. There was no significant difference of fat in pickling duration. Fermentation time had no significant difference on fat content. There was a declining trend of moisture and carbohydrate contents; an increasing trend of ash, protein, fibre in samples during 8 days of pickling. There was no significant difference of proximate compositions between pickled gloma eggplants at day $6^{\text {th }}$ and day $8^{\text {th }}$. Therefore, the length of fermentation could be shorted to 6 days instead of 8 days. Our results 
Table 1. Effect of fermentation time (days) to nutritional proximate (\%) of raw and pickled eggplant

\begin{tabular}{lccccc}
\hline $\begin{array}{l}\text { Fermentation } \\
\text { time (days) }\end{array}$ & 0 & 2 & 4 & 6 & 8 \\
\hline Moisture (\%) & $91.83 \pm 0.01^{\mathrm{a}}$ & $91.34 \pm 0.00^{\mathrm{ab}}$ & $90.76 \pm 0.03^{\mathrm{b}}$ & $90.15 \pm 0.02^{\mathrm{bc}}$ & $89.48 \pm 0.01^{\mathrm{c}}$ \\
Ash (\%) & $0.82 \pm 0.00^{\mathrm{b}}$ & $0.83 \pm 0.02^{\mathrm{b}}$ & $0.87 \pm 0.01^{\mathrm{ab}}$ & $0.89 \pm 0.00^{\mathrm{a}}$ & $0.90 \pm 0.03^{\mathrm{a}}$ \\
Protein (\%) & $1.05 \pm 0.03^{\mathrm{b}}$ & $1.07 \pm 0.01^{\mathrm{b}}$ & $1.13 \pm 0.00^{\mathrm{ab}}$ & $1.18 \pm 0.03^{\mathrm{a}}$ & $1.20 \pm 0.01^{\mathrm{a}}$ \\
Fat (\%) & $0.42 \pm 0.02^{\mathrm{a}}$ & $0.41 \pm 0.03^{\mathrm{a}}$ & $0.42 \pm 0.02^{\mathrm{a}}$ & $0.40 \pm 0.01^{\mathrm{a}}$ & $0.43 \pm 0.00^{\mathrm{a}}$ \\
Fibre (\%) & $2.46 \pm 0.00^{\mathrm{b}}$ & $2.49 \pm 0.01^{\mathrm{b}}$ & $2.53 \pm 0.00^{\mathrm{ab}}$ & $2.59 \pm 0.02^{\mathrm{a}}$ & $2.60 \pm 0.03^{\mathrm{a}}$ \\
Carbohydrate (\%) & $4.07 \pm 0.03^{\mathrm{a}}$ & $4.00 \pm 0.02^{\mathrm{a}}$ & $3.89 \pm 0.01^{\mathrm{ab}}$ & $3.76 \pm 0.00^{\mathrm{b}}$ & $3.71 \pm 0.02^{\mathrm{b}}$ \\
\hline
\end{tabular}

Figures are the mean of three replications \pm standard deviation $(n=3)$; Figures in row followed by the different letter/s $(a, b$, c) are differed significantly ( $\alpha=P=0.05$ ). Letter (a) represented the highest value while letter (c) represented the lowest value

Table 2. Effect of fermentation time (days) to mineral contents $(\mathrm{mg} / 100 \mathrm{~g}$ ) of raw and pickled

\begin{tabular}{lccccc}
\hline $\begin{array}{l}\text { Fermentation } \\
\text { time (days) }\end{array}$ & 0 & 2 & 4 & 6 & 8 \\
\hline $\mathrm{Na}$ & & & & & \\
$\mathrm{K}$ & $2.78 \pm 0.02^{\mathrm{c}}$ & $2.85 \pm 0.01^{\mathrm{bc}}$ & $2.97 \pm 0.03^{\mathrm{b}}$ & $3.16 \pm 0.01^{\mathrm{ab}}$ & $3.35 \pm 0.03^{\mathrm{a}}$ \\
$\mathrm{Ca}$ & $125.81 \pm 1.29^{\mathrm{c}}$ & $129.45 \pm 1.16^{\mathrm{bc}}$ & $133.28 \pm 1.35^{\mathrm{b}}$ & $137.20 \pm 1.04^{\mathrm{ab}}$ & $142.53 \pm 1.22^{\mathrm{a}}$ \\
$\mathrm{Mg}$ & $8.19 \pm 0.01^{\mathrm{c}}$ & $8.30 \pm 0.02^{\mathrm{bc}}$ & $8.42 \pm 0.00^{\mathrm{b}}$ & $8.51 \pm 0.00 \mathrm{a}^{\mathrm{b}}$ & $8.67 \pm 0.02^{\mathrm{a}}$ \\
$\mathrm{P}$ & $14.67 \pm 0.02^{\mathrm{c}}$ & $14.98 \pm 0.00^{\mathrm{bc}}$ & $15.56 \pm 0.03^{\mathrm{b}}$ & $15.97 \pm 0.01^{\mathrm{ab}}$ & $16.43 \pm 0.00^{\mathrm{a}}$ \\
$\mathrm{Fe}$ & $23.74 \pm 0.18^{\mathrm{c}}$ & $24.03 \pm 0.13^{\mathrm{bc}}$ & $24.49 \pm 0.09^{\mathrm{b}}$ & $24.94 \pm 0.15^{\mathrm{ab}}$ & $24.61 \pm 0.12^{\mathrm{a}}$ \\
& $0.23 \pm 0.03^{\mathrm{c}}$ & $0.28 \pm 0.01^{\mathrm{bc}}$ & $0.34 \pm 0.00^{\mathrm{b}}$ & $0.41 \pm 0.02^{\mathrm{ab}}$ & $0.49 \pm 0.03^{\mathrm{a}}$
\end{tabular}

Figures are the mean of three replications \pm standard deviation $(n=3)$; Figures in row followed by the different letter/s $(a, b$, c) are differed significantly ( $\alpha=P=0.05$ ). Letter (a) represented the highest value while letter (c) represented the lowest value

were similar to findings by Eletta et al., ${ }^{26}$ those of gboma eggplant (S. macrocarpon) were 92.00 $\pm 0.43,0.80 \pm 0.03,0.52 \pm 0.02,0.15 \pm 0.02,2.50$ \pm 0.02 and $2.50 \pm 0.02 \%$, respectively. Similar data were mentioned on one study conducted by Agoreyo et al. ${ }^{27}$ Fat content in gboma eggplant was quite low at $0.17 \pm 0.01 \% .^{3}$ High fibre and low-fat contents in gboma eggplant were ideal for minimizing over weight load, dysfunctions of constipation, carcinoma of the colon and rectum, diverticulitis and atherosclerosis. ${ }^{28-30}$ The high fibre and low carbohydrate contents in gboma eggplant would be a positive signal for controlling of diabetes melitus. ${ }^{31}$ The ash content in gboma eggplant was $0.47 \pm 0.02 \%$ by finding of Chinedu et al. ${ }^{3}$ Carbohydrate content in gboma eggplant was reported at $4.42 \pm 0.12 \% .^{3}$ One survey of Muhammad and Senay ${ }^{32}$ reported that nutritional contents of eggplant consisted of carbohydrate (4.70-5.88\%), dietary fibre (2.80-3.40\%), fat (0.18$0.20 \%)$, protein $(0.80-1.01 \%)$. Abundant fibre in eggplant was useful for digestion by reducing toxic and harmful substances from stomach thus preventing stomach and colon cancer. ${ }^{33} \mathrm{High}$ carbohydrate, fit fibre and low protein contents induced eggplant to be an ideal ingredient for fermentation. ${ }^{34}$ Variety of pickled products contained precious resources of vitamins, fibres, minerals, proteins, carbohydrates and lipids. ${ }^{35-37}$ Abundant quantities of dietary fibres, vitamins and proteins were accumulated from pickling of garlic. $^{38}$

Minerals were essential factors inevitable for human body. They played important role as co-factors for different physiological and metabolic pathways. ${ }^{39}$ Mineral contents of raw and pickled gboma eggplant were presented in Table 2. There was an increasing trend of mineral contents from raw to pickled gboma eggplant during 8 days of pickling. There was no significant difference of mineral content between pickled gloma eggplants at day 6th and day $8^{\text {th }}$. Therefore, the length of fermentation could be shorted to 6 days instead of 8 days. One survey of Muhammad and Senay ${ }^{33}$ reported that mineral contents of eggplant consisted of $\mathrm{Ca}$ (7.4 -9.0 mg/100 g), Fe (0.20-0.24 $\mathrm{mg} / 100 \mathrm{~g}), \mathrm{Mg}(13.5-14 \mathrm{mg} / 100 \mathrm{~g}), \mathrm{Mn}(0.20-0.25$ $\mathrm{mg} / 100 \mathrm{~g}), \mathrm{P}(22.5$ - $25 \mathrm{mg} / 100 \mathrm{~g}), \mathrm{K}(129$ - 130 
Table 3. Effect of fermentation time (days) to phenyllactic acid (mg/g), ascorbic acid content (mg/100 g), pH and titratable acidity ( $\mathrm{mg}$ lactic acid/100 g) of raw and pickled eggplant

\begin{tabular}{lccccc}
\hline $\begin{array}{l}\text { Fermentation } \\
\text { time (days) }\end{array}$ & 0 & 2 & 4 & 6 & 8 \\
\hline Phenyllactic acid (mg/g) & $7.31 \pm 0.04^{\mathrm{c}}$ & $8.65 \pm 0.03^{\mathrm{bc}}$ & $9.76 \pm 0.00^{\mathrm{b}}$ & $11.03 \pm 0.02^{\mathrm{ab}}$ & $12.46 \pm 0.01^{\mathrm{a}}$ \\
Ascorbic acid (mg/100 g) & $65.42 \pm 0.03^{\mathrm{c}}$ & $71.18 \pm 0.00^{\mathrm{bc}}$ & $83.50 \pm 0.01^{\mathrm{b}}$ & $96.15 \pm 0.04^{\mathrm{ab}}$ & $109.23 \pm 0.02^{\mathrm{a}}$ \\
$\mathrm{pH}$ & $6.79 \pm 0.01^{\mathrm{a}}$ & $5.13 \pm 0.02^{\mathrm{ab}}$ & $4.86 \pm 0.03^{\mathrm{b}}$ & $4.50 \pm 0.02^{\mathrm{bc}}$ & $4.12 \pm 0.00^{\mathrm{c}}$ \\
Titratable acidity & $0.15 \pm 0.02^{\mathrm{c}}$ & $4.51 \pm 0.01^{\mathrm{b}}$ & $6.24 \pm 0.02^{\mathrm{ab}}$ & $7.69 \pm 0.03^{\mathrm{a}}$ & $7.81 \pm 0.03^{\mathrm{a}}$ \\
(mg lactic acid/100 g) & & & & & \\
\hline
\end{tabular}

Figures are the mean of three replications \pm standard deviation $(n=3)$; Figures in row followed by the different letter/s $(a, b, c)$ are differed significantly $(\alpha=P=0.05)$. Letter (a) represented the highest value while letter (c) represented the lowest value.

Table 4. Effect of fermentation time (days) to anti-nutritional contents of raw and pickled eggplant

\begin{tabular}{lccccc}
\hline $\begin{array}{l}\text { Fermentation } \\
\text { time (days) }\end{array}$ & 0 & 2 & 4 & 6 & 8 \\
\hline Tannin $(\mathrm{mg} / \mathrm{g})$ & $65.14 \pm 1.05^{\mathrm{a}}$ & $31.06 \pm 0.63^{\mathrm{b}}$ & $24.35 \pm 0.58^{\mathrm{bc}}$ & $13.51 \pm 0.32^{\mathrm{c}}$ & $11.54 \pm 0.26^{\mathrm{c}}$ \\
Phytate $(\mathrm{mg} / 100 \mathrm{~g})$ & $126.53 \pm 3.41^{\mathrm{a}}$ & $81.45 \pm 2.75^{\mathrm{ab}}$ & $54.13 \pm 1.64^{\mathrm{b}}$ & $22.74 \pm 0.83^{\mathrm{bc}}$ & $9.37 \pm 0.35^{\mathrm{c}}$ \\
Oxalate $(\mathrm{mg} / 100 \mathrm{~g})$ & $241.27 \pm 0.00^{\mathrm{a}}$ & $169.32 \pm 0.01^{\mathrm{ab}}$ & $97.46 \pm 0.02^{\mathrm{b}}$ & $31.25 \pm 0.01^{\mathrm{bc}}$ & $3.02 \pm 0.00^{\mathrm{c}}$ \\
$\begin{array}{l}\text { Steroidal glycoalkaloid } \\
\text { (mg solamargine/kg) }\end{array}$ & $49.62 \pm 0.03^{\mathrm{a}}$ & $31.53 \pm 0.02^{\mathrm{ab}}$ & $19.08 \pm 0.01^{\mathrm{b}}$ & $5.42 \pm 0.00^{\mathrm{bc}}$ & $0.86 \pm 0.02^{\mathrm{c}}$ \\
\hline
\end{tabular}

Figures are the mean of three replications \pm standard deviation $(n=3)$; Figures in row followed by the different letter/s $(a, b, c)$ are differed significantly ( $\alpha=P=0.05$ ). Letter (a) represented the highest value while letter (c) represented the lowest value.

$\mathrm{mg} / 100 \mathrm{~g}), \mathrm{Zn}(0.10-0.16 \mathrm{mg} / 100 \mathrm{~g})$. According to findings by Kortei et al. ${ }^{40}$ in analyzing bioactive constituents in raw gboma eggplant, mineral contents were noticed in range between $8.35 \pm 0.06$ $-10.09 \pm 0.00 \mathrm{mg} / \mathrm{kg}$ for $\mathrm{Fe}, 29.58 \pm 0.12-30.83 \pm 0.02$ $\mathrm{mg} / \mathrm{kg}$ for $\mathrm{Mg}$ and $11.50 \pm 0.04-35.03 \pm 0.09 \mathrm{mg} / \mathrm{kg}$ for $\mathrm{Na}$. Iron was a beneficial mineral participating in hemoglobin manufacturing and oxygenation of red blood cells, metabolism and circulation. ${ }^{41}$ Magnesium was a key co-factor of various regulatory enzymes, participating in the power movement reaction..$^{42}$ It's related to enzymatic response of carbohydrate glycolysis. Its shortage might lead to chronic ailments. Sodium involved in the infusion of nerve impulses and kept an osmotic equilibrium of the cells in the living tissue. ${ }^{40} \mathrm{Mg}$, $\mathrm{Mn}, \mathrm{P}$ were important minerals for healthy bone. Fe was useful for teenagers, pregnant and lactating mothers. ${ }^{43}$

There was accumulation of phenyllactic acid, ascorbic acid content and titratable acidity with exception of $\mathrm{pH}$ during 8 days of pickling (Table 3). There was no significant difference of phenyllactic acid, ascorbic acid content, pH and titratable acidity between pickled gloma eggplants at day 6 th and day $8^{\text {th }}$. Therefore, the length of fermentation could be shorted to 6 days instead of 8 days. Phenyllactic acid as an organic acid released from lactic acid bacteria effectively controlled proliferation of yeast and fungi. ${ }^{15}$ Phenyllactic acid was presented in pickle products at trace amount. ${ }^{44} \mathrm{It}^{\prime} \mathrm{s}$ believed as the main element responsible for antifungal property and extended stability. ${ }^{45,46}$ Ascorbic acid content in eggplant berry was around $400-700 \mathrm{mg} / \mathrm{kg}$. ${ }^{47}$ Abundant vitamin C content in pickled foodstuffs might minimize benzene accumulation resulting to less cellular vulnerability. ${ }^{48}$

After washing and slicing, cut eggplant was immersed in brine to partly reduce fruit bitterness. Anti-nutrient contents like tannin, phytate, oxalate, steroidal glycoalkaloid greatly decreased in raw and pickled eggplant during 8 days of pickling (Table 4). There was no significant difference of anti-nutritional contents between pickled gloma eggplants at day 6 th and day $8^{\text {th }}$. Therefore, the length of fermentation could be shorted to 6 days instead of 8 days. Tannin was structured as a hydroxyl group bonded to an aromatic ring. ${ }^{49}$ Tannin had a powerful binding 
capacity with proteins and minerals as well as non-specific enzyme inhibition. Tannin bound strictly with the $-\mathrm{NH} 2$ segments of peptides and proteins limiting their metabolism. ${ }^{51}$ Tannin retarded $\alpha$-amylase, trypsin and lipase resulting to lower metabolism of carbohydrates, proteins and lipids, respectively. ${ }^{51-53}$ Moreover, tannin also combined with minerals leading to deficiency of micronutrients. ${ }^{54}$ Tannin was mostly decomposed in gastrointestinal route by intestine microflora to release metabolites ready for absorption in blood; the remaining was discharged via manure..$^{55,56}$ Immersion in pickling process might reduce tannin content via diffusion mechanism. Phytate was salt form of phytic acid, myo-inositol hexakis dihydrogenphosphate. Phytate had negative charge therefore it easily bound with cation to create insoluble complex. Phytate chelated with amino acid resulting to deficiency of protein digestibility and bioavailability. ${ }^{57}$ Phytate also interacted with carbohydrate via hydrogen bonding with a phosphate group limiting starch solubility and bioavailability. ${ }^{58}$ Phytate was degraded in gastric and tiny gut by phosphatase. In gastric, phytate interacted with mineral to form mineral-phytate in dissolved status. In tiny gut, mineral-phytate began precipitated induced to low digestibility of mineral. ${ }^{59}$ At colon segment, phytate was degraded by phytase originated from gastrointestinal microbiota. High content of $\mathrm{Ca}^{2+}$ and $\mathrm{Mg}^{2+}$ retarded the phytate dissolution and decomposition. Microbials in colon participated in phytate hydrolysis to lower phytate content in manure. ${ }^{60}$ Phytate was mostly metabolized in tiny gut; a small amount was absorbed in blood. ${ }^{59}$ Immersion in pickling process resulted to phytate lost through leaching and enzymatic hydrolysis. ${ }^{61}$ $96 \%$ phytate in legume was decomposed in fermentation. ${ }^{62}$ Oxalate had a strong ability to create insoluble particles via chelating different minerals, and vital micronutrients like iron, zinc and calcium. ${ }^{63}$ In oral intake, oxalate constrained with minerals in the gastrointestinal route and limited their metabolism. Metabolism of oxalate happened in gastric, tiny colon and massive colon. ${ }^{64}$ The huge gut was the main location for oxalate metabolism; soluble oxalate was metabolized via negative disperse..$^{65}$ Unavailable oxalate would be discharged in manure. ${ }^{66}$ Soluble oxalate combined with calcium to turn into insoluble calcium oxalate, condensed in renal and urinary route, saturated into calcium oxalate crystals. ${ }^{67}$ Oxalate oxidase, oxalate decarboxylase and oxalyICoA synthetase originated from microorganisms leading to oxalate reduction during pickling. ${ }^{68,69} 74 \%$ reduction of oxalate content in cocoyam was noticed after fermentation. ${ }^{70}$ Steroidal glycoalkaloid (solanidine) was believed as poisonous substance represented in gboma eggplant. It was $\mathrm{N}$ based substance including $\mathrm{C} 27$ basic skeleton and cholestane moiety in Solanaceae class. It's transformed by glycosylation of the alkamine steroidal skeleton at C-3b position. ${ }^{71}$ This compound created a preventive mechanism against pathogen, pest, insect, herbivorous fauna and human. ${ }^{72}$ Neurological symptoms and recession of the core mental chain were observed from consumption of raw gboma eggplant due to steroidal glycoalkaloid. ${ }^{73}$ The existence of harmful steroidal glycoalkaloid inflicted diarrhoea, cancer and over condensation of calcium in cells. ${ }^{74}$ Hence, steroidal glycoalkaloid should be eliminated to trace level through pickling.

During 8 days of picking, remarkable increments of total phenolic, flavonoid, DPPH free radical scavenging and FRAP ferric reducing

Table 5. Effect of fermentation time (days) to phytochemical and antioxidant properties of raw and pickled eggplant

\begin{tabular}{lccccc}
\hline $\begin{array}{l}\text { Fermentation } \\
\text { time (days) }\end{array}$ & 0 & 2 & 4 & 6 & 8 \\
\hline TPC (mg GAE/100 g) & $39.52 \pm 0.18^{\mathrm{c}}$ & $45.26 \pm 0.20^{\mathrm{bc}}$ & $49.31 \pm 0.17^{\mathrm{b}}$ & $54.27 \pm 0.26^{\mathrm{ab}}$ & $60.48 \pm 0.13^{\mathrm{a}}$ \\
TFC (mg QE/100 g) & $23.39 \pm 0.05^{\mathrm{c}}$ & $25.71 \pm 0.11^{\mathrm{bc}}$ & $28.02 \pm 0.08^{\mathrm{b}}$ & $31.15 \pm 0.12^{\mathrm{ab}}$ & $36.20 \pm 0.07^{\mathrm{a}}$ \\
DPPH (mg TE/100 g) & $27.94 \pm 0.04^{\mathrm{c}}$ & $32.17 \pm 0.03^{\mathrm{bc}}$ & $39.15 \pm 0.05^{\mathrm{b}}$ & $44.24 \pm 0.01^{\mathrm{ab}}$ & $51.04 \pm 0.03^{\mathrm{a}}$ \\
FRAP (mg TE/100 g) & $14.82 \pm 0.02^{\mathrm{c}}$ & $15.49 \pm 0.01^{\mathrm{bc}}$ & $16.03 \pm 0.03^{\mathrm{b}}$ & $16.85 \pm 0.02^{\mathrm{ab}}$ & $17.31 \pm 0.04^{\mathrm{a}}$ \\
\hline
\end{tabular}

Figures are the mean of three replications \pm standard deviation $(n=3)$; Figures in row followed by the different letter/s $(a, b, c)$ are differed significantly ( $\alpha=P=0.05)$. Letter (a) represented the highest value while letter (c) represented the lowest value. 
Table 6. Effect of fermentation time (days) to texture profile (sensory score) of raw and pickled eggplant

\begin{tabular}{lccccc}
\hline $\begin{array}{l}\text { Fermentation } \\
\text { time (days) }\end{array}$ & 0 & 2 & 4 & 6 & 8 \\
\hline Hardness & $12.05 \pm 0.04^{\mathrm{a}}$ & $11.86 \pm 0.01^{\mathrm{ab}}$ & $11.52 \pm 0.00^{\mathrm{b}}$ & $11.35 \pm 0.03^{\mathrm{bc}}$ & $11.18 \pm 0.02^{\mathrm{c}}$ \\
Crispness & $8.29 \pm 0.00^{\mathrm{a}}$ & $8.17 \pm 0.02^{\mathrm{ab}}$ & $8.05 \pm 0.03^{\mathrm{b}}$ & $7.96 \pm 0.04^{\mathrm{bc}}$ & $7.83 \pm 0.01^{\mathrm{c}}$ \\
Fracturability & $10.41 \pm 0.03^{\mathrm{a}}$ & $10.19 \pm 0.01^{\mathrm{ab}}$ & $10.03 \pm 0.02^{\mathrm{b}}$ & $9.87 \pm 0.01^{\mathrm{bc}}$ & $9.73 \pm 0.04^{\mathrm{c}}$ \\
Crunchiness & $7.93 \pm 0.02^{\mathrm{a}}$ & $7.84 \pm 0.03^{\mathrm{ab}}$ & $7.69 \pm 0.01^{\mathrm{b}}$ & $7.51 \pm 0.02^{\mathrm{bc}}$ & $7.38 \pm 0.00^{\mathrm{c}}$ \\
\hline
\end{tabular}

Figures are the mean of three replications \pm standard deviation $(n=3)$; Figures in row followed by the different letter/s $(a, b, c)$ are differed significantly ( $\alpha=P=0.05$ ). Letter (a) represented the highest value while letter (c) represented the lowest value.

antioxidant of raw and pickled eggplant were presented in Table 5. There was no significant difference of phytochemical and antioxidant properties between pickled gloma eggplants at day $6^{\text {th }}$ and day $8^{\text {th }}$. Therefore, the length of fermentation could be shorted to 6 days instead of 8 days. Eggplant was ranked among top ten vegetables containing abundant phenolic and flavonoid substances with excellent antioxidant property. ${ }^{75,77}$ They involved a promising conducive role on hyperlipidemia in animals ${ }^{78}$ and a humble validity on hypercholesterolemia in humans. ${ }^{79}$ Phenolics possessed numerous biological characteristics with powerful antioxidant activity against cancer and cardiovascular syndromes. ${ }^{80}$ Flavonoids were highly evaluated as promising health-promoting components owing to their antioxidative, anti-cancer, and cardiovascular defend. ${ }^{81}$ DPPH might be beneficial in limiting the degree of reactive nitrogen species in life cells. ${ }^{82}$ The evaluation of antioxidant capacity to reduce iron reflected the power of one constituent to move an electron or hydrogen atom from another element to and an antioxidant capability to reduce the oxidized secondary substances in peroxidation. ${ }^{83}$ Phytochemical constituents were beneficial in scavenging toxic free radicals in the body emitted by numerous biological tension and ailments. ${ }^{84}$ According to findings of Eletta et al., ${ }^{26}$ raw gboma eggplant had a high DPPH scavenging activity with a low IC50 $33.56 \mu \mathrm{g} / \mathrm{ml}$. According to findings by Kortei et al. ${ }^{40}$ in analyzing bioactive constituents in eggplant, total phenolic, flavonoid, DPPH, FRAP in raw gboma eggplant (S. macrocarpon) extract were in range $23.51 \pm 0.37 \pm 0.00$ to $40.61 \pm 0.00 \mu \mathrm{L}$ $\mathrm{GAE} / 10 \mu \mathrm{L}, 62.29 \pm 0.38$ to $479.51 \pm 0.26 \mu \mathrm{L} \mathrm{CE} / 10$ $\mu \mathrm{L}, 18.79 \pm 2.92$ to $60.93 \pm 13.42 \%, 0.023 \pm 0.00$ to $0.092 \pm 0.00 \%$, respectively. Lactic acid bacteria accompanied by fermented pickle biosynthesized vital vitamins. ${ }^{85}$ Pickling facilitated to release plentiful functional elements (peptides and amino acids) and phytochemical antioxidants (phenols, flavonoids and sterols). ${ }^{86}$ The increased of antioxidants via pickling could be due to the more accumulation of soluble solid substances. Moreover, the supplementation of sugar in the pickling step was proven to create favorable condition for the biosynthesis of reduced phenolics as well as prevention of the leakage of antioxidant components from the plant tissue. ${ }^{87,88}$ Pickling effectively maintained and restored natural therapeutic substances and antioxidant properties of plants. ${ }^{89}$ Phytochemical constituents in eggplant were useful to cell membranes and promote the memory ability of the cerebral by guarding its cell against brain tumor caused by free radical groups. $^{32}$

Texture profiles of hardness, crispness, fracturability, crunchiness revealed a minor reduction of sensory scores during 8 days of fermentation (Table 6). There was no significant difference of texture profile (sensory score) between pickled gloma eggplants at day 6th and day $8^{\text {th }}$. Therefore, the length of fermentation could be shorted to 6 days instead of 8 days. Texture profiles of pickled eggplant were greatly affected by dimension and maturity of raw material as soluble dry matters involved into the fermentation process. Hardness was depicted as the strength needed to compact the pattern at first stung with anchors of 0 for tender to 15 for sturdy. Crispness was depicted at the more, higher peak sounds released as the pattern is mashed with the molar teeth. Fracturability was depicted as strength with which the pattern breaks when putting pattern between molars and stung down absolutely down at a quick speed. Crunchiness was depicted as a mono lower-toned sound to 
Table 7. Effect of fermentation time (days) to microbiological load (log CFU/g) of raw and pickled eggplant

\begin{tabular}{lccccc}
\hline $\begin{array}{l}\text { Fermentation } \\
\text { time (days) }\end{array}$ & 0 & 2 & 4 & 6 & 8 \\
\hline LAB (log CFU/g) & $0.19 \pm 0.01^{\mathrm{e}}$ & $2.48 \pm 0.03^{\mathrm{d}}$ & $4.35 \pm 0.02^{\mathrm{c}}$ & $6.91 \pm 0.03^{\mathrm{b}}$ & $9.15 \pm 0.01^{\mathrm{a}}$ \\
Bacillus sp. (log CFU/g) & $0.31 \pm 0.02^{\mathrm{c}}$ & $1.94 \pm 0.01^{\mathrm{bc}}$ & $2.57 \pm 0.00^{\mathrm{b}}$ & $3.78 \pm 0.02^{\mathrm{ab}}$ & $4.63 \pm 0.00^{\mathrm{a}}$ \\
Micrococcus sp. (log CFU/g) & $2.05 \pm 0.03^{\mathrm{a}}$ & $1.41 \pm 0.02^{\mathrm{ab}}$ & $0.97 \pm 0.01^{\mathrm{b}}$ & $0.32 \pm 0.00^{\mathrm{bc}}$ & $0.09 \pm 0.02^{\mathrm{c}}$ \\
S. aureus (log CFU/g) & $0.92 \pm 0.01^{\mathrm{b}}$ & $1.28 \pm 0.00^{\mathrm{a}}$ & $1.05 \pm 0.02^{\mathrm{ab}}$ & $0.33 \pm 0.01^{\mathrm{c}}$ & $0.00 \pm 0.00^{\mathrm{d}}$ \\
Yeast (log CFU/g) & $0.27 \pm 0.02^{\mathrm{c}}$ & $0.58 \pm 0.03^{\mathrm{bc}}$ & $1.63 \pm 0.01^{\mathrm{a}}$ & $1.28 \pm 0.03^{\mathrm{ab}}$ & $0.91 \pm 0.01^{\mathrm{b}}$ \\
Fungi (log CFU/g) & $0.11 \pm 0.00^{\mathrm{c}}$ & $0.37 \pm 0.01^{\mathrm{bc}}$ & $1.42 \pm 0.00^{\mathrm{a}}$ & $1.09 \pm 0.02^{\mathrm{ab}}$ & $0.84 \pm 0.03^{\mathrm{b}}$
\end{tabular}

Figures are the mean of three replications \pm standard deviation $(n=3)$; Figures in row followed by the different letter/s $(a, b, c, d$, e) are differed significantly ( $\alpha=P=0.05$ ). Letter (a) represented the highest value while letter (e) represented the lowest value.

release mastication. Brine inhibited the activation of pectinolytic enzymes (polygalacturonase) that were responsible for softening of sample structure. ${ }^{90}$ As a result of lactic fermentation, plant would have an extended stability, translucent image, and sturdy texture and pickle aroma. ${ }^{89}$

Brine affected to active microorganism and retarded softening of eggplant tissue. Brine supported for homofermentative lactic acid bacteria during pickling. It's very important to keep eggplant fully submerged in brine. In the present study, brine ( $5 \%$ salt) submerged eggplant for 8 days at ambient temperature. Lactic acid bacteria, Bacillus significantly proliferated; meanwhile, Micrococcus and S. aureus were absolutely retarded at in pickled eggplant. Yeast and fungi increased in the first 4 days and decreased afterwards (Table 7). There was no significant difference of microbiological load (with exception of $S$. aureus) between pickled gloma eggplants at day $6^{\text {th }}$ and day $8^{\text {th }}$. Therefore, the length of fermentation could be shorted to 6 days instead of 8 days. Lactobacillus sp. was commonly encountered microorganisms involved in pickling of eggplant. ${ }^{91}$ They were Gram [+], catalase [-], anaerobic, microaerophilic and aero-salt-sugartolerant in compulsory fermentative behavior. ${ }^{92}$ Lactic acid derived from the natural fermentation retarded the growth and proliferation of spoilage and pathogen microorganisms. ${ }^{93}$ Lactic acid bacteria ( $L A B$ ) released heterogeneous flavour components, specific bacteriocins, and exclusive exopolysaccharides accounting for essential properties, like structure, flavour, and durability of the pickled products..$^{94}$ LAB also participated in detoxification and degeneration of mycotoxins to minimize potentially biological hazards. Bacillus sp. had stick-figure, Gram [+], catalase [+], compulsory aerobic or facultative anaerobic. Bacillus sp. was listed safely to create favourable condition for quick occupation of the healthy microbiota in the gastrointestinal routs, retardation of the assault and placement of intestinal pathogens and reduction of cholesterol. ${ }^{95}$ Micrococcus belonged to Gram [+], aerobic, cocci, nonspore making, non-motile and [+] response to catalase, coagulase, deoxyribonuclease check. ${ }^{96}$ S. aureus was foodborne pathogen isolated from home-made vegetable pickle. ${ }^{97}$ Different yeast species such as Candida, Saccharomyces, Schizosaccharomyces, and Torulopsis etc were found in the fermented pickle. ${ }^{98}$ Harmless yeasts proliferated on the surface and stabilized to the bottom. ${ }^{10}$ Fungal species had an important role in pickling by producing lactic acid, fumaric acid and ethanol. They secured suitability and quality in the finished product. ${ }^{99}$

\section{CONCLUSION}

Eggplant was mostly cultivated for vegetable and medicinal goals. Raw gboma eggplant contained abundant nutritional, antinutritional and therapeutic components. Pickled eggplant had a distinctive sensory attributes and microbial safety benefits. During 8 days of fermentation, pickled eggplant had diversified nutritional proximate, low anti-nutritional contents, high phytochemical contents, desirable textural sensory characteristics and safe microbial indicators which were available for a healthy consumption. Raw gboma eggplant should be converted into pickled form as a functional food with nutritional and medicinal advantages for humans. 


\section{ACKNOWLEDGMENTS}

I would like to express my heartfelt thanks to Mrs. Tran Thi Kieu Oanh for providing raw material.

\section{FUNDING}

This study was supported by Thu Dau Mot University, Binh Duong province, Vietnam.

\section{DATA AVAILABILITY}

All datasets generated or analyzed during this study are included in the manuscript.

\section{ETHICS STATEMENT}

This article did not contain any studies with human participants or animals performed by the author.

\section{REFERENCES}

1. Halinski LP, Topolewska A, Rynkowska A, et al. Impact of plant domestication on selected nutrient and anti-nutrient compounds in Solanaceae with edible leaves (Solanum spp.). Genet Resour Crop Evol. 2019;66(1):89-103. doi: 10.1007/s10722-018-0699-1

2. Osei MK, Banful B, Osei CK, Oluoch MO. Characterization of African eggplant for morphological characteristics. J Agric Sci Technol. 2010;4(3):33-37.

3. Chinedu SN, Olasumbo AC, Eboji OK, Emiloju OC, Arinola OK, Dania DI. Proximate and phytochemical analyses of Solanum aethiopicum L. and Solanum macrocarpon L. fruits. Research Journal of Chemical Science. 2011;1(3):63-71.

4. Vinson JA, Hao Y, Su X, Zubik L. Phenol antioxidant quantity and quality in foods: vegetables. J Agric Food Chem. 1998;46:3630-3634. doi: 10.1021/jf980295o

5. Nisha P, Abdul Nazar P, Jayamurthy P. A comparative study on antioxidant activities of different varieties of Solanum melongena. Food Chem Toxicol. 2009;47(10):2640-2644. doi: 10.1016/j. fct.2009.07.026

6. Matsubara K, Kaneyuki T, Miyake T, Mori M. Antiangiogenic activity of Nasunin, an antioxidant anthocyanin, in eggplant peels. J Agric Food Chem. 2005;53(16):6272-6275. doi: 10.1021/jf050796r

7. Han SW, Tae J, Kim JA, et al. The aqueous extract of Solanum melongena inhibits PAR2 agonist-induced inflammation. Clinical Chimica Acta. 2003;328(1-2):3944. doi: 10.1016/s0009-8981(02)00377-7

8. Im K, Lee JY, Byeon H, et al. In Vitro antioxidative and anti-inflammatory activities of the ethanol extract of eggplant (Solanum melongena) stalks in macrophage RAW 264.7 cells. Food Agric Immunol. 2016;27:758771. doi: 10.1080/09540105.2016.1150427

9. Howard LR, Buescher RW. Cell wall characteristics and firmness of fresh pack cucumber pickles affected by pasteurization and calcium chloride. J Food Biochem. 1990;14:31-43. doi: 10.1111/j.1745-4514.1990. tb00819.x

10. Sudhanshu SB, Aly FES, Riadh H, Awanish K. Traditionally fermented pickles: How the microbial diversity associated with their nutritional and health benefits? J Funct Foods. 2020;70:103971. doi: 10.1016/j.jff.2020.103971

11. Liong MT, Shah NP. Acid and bile tolerance and cholesterol removal ability of Lactobacilli strains. J Dairy Sci. 2005;88(1):55-66. doi: 10.3168/jds.s00220302(05)72662-x

12. Miller KC, Mack G, Knight KL. Electrolyte and plasma changes after ingestion of pickle juice, water, and a common carbohydrate-electrolyte solution. Journal of Athletic Training. 2009;44(5):454-461. doi: 10.4085/1062-6050-44.5.454

13. Nurul SR, Asmah R. Evaluation of antioxidant properties in fresh and pickled papaya. Int Food Res J. 2012;19(3):1117-1124. http://www.ifrj.upm.edu. my/19\%20(03)\%202012/(44)\%20IFRJ\%2019\%20 (03)\%202012\%20Asmah.pdf

14. AOAC. Official method of analysis. $17^{\text {th }}$ ed. Washington DC: Association of Official Analytical Chemists. 2000.

15. Armaforte E, Carri S, Ferri G, Caboni MF. Highperformance liquid chromatography determination of phenyllactic acid in MRS broth. Journal of Chromatography. 2006;1131(1-2):281-284. doi: 10.1016/j.chroma.2006.07.095

16. AOAC. Official method of analysis. $18^{\text {th }}$ ed. Washington DC: Association of Official Analytical Chemists. 2005.

17. Adegunwa M, Alamu E, Omitogun L. Effect of processing on the nutritional contents of yam and cocoyam tubers. Journal of Applied Bioscience. 2011;4:3086-3092.

18. Wheeler X, Ferrel R. A method for phytic acid determination in wheat and wheat fractions. Cereal Chemistry. 1971;48:312-320.

19. Falade OS, Dare AF, Bello MO, Osuntogun BO, Adewusi SRA. Varietal changes in proximate composition and the effect of processing on the ascorbic acid content of some Nigerian vegetables. Journal of Food Technology. 2004;2(2):103-108. https://medwelljournals.com/ abstract/?doi=jftech.2004.103.108

20. Eanes RC, Tek N, Kirsoy O, Frary A, Doganlar S, Almeida AE. Development of Practical HPLC methods for the separation and determination of eggplant steroidal glycoalkaloids and their aglycones. J Liq Chromatogr Relat Technol. 2008;31(7):984 -1000. doi: 10.1080/10826070801924741

21. Singleton VL, Rossi JAJR. Colorimetry of total phenolics with phosphomolybdic phosphotungstic acid reagents. Am J Enol Vitic. 1965;16:144-158.

22. Mandal S, Patra A, Samanta A, et al. Analysis of phytochemical profile of Terminalia arjuna bark extract with antioxidative and antimicrobial properties. Asian Pac J Trop Biomed. 2013;3(12):960-966. doi: 10.1016/ s2221-1691(13)60186-0

23. Andriana Y, Xuan TD, Quy TN, Minh TN, Van TM, Viet TD. Antihyperuricemia, antioxidant, and antibacterial activities of Tridax procumbens L. Foods. 2019;8(1):21. doi: 10.3390/foods 8010021

24. Benzie IFF, Strain JJ. The ferric reducing ability of plasma (FRAP) as a measure of antioxidant power: 
The FRAP assay. Anal Biochem. 1996;239(1):70-76. doi: 10.1006/abio.1996.0292

25. Meilgaard MC, Civille GV, Carr BT. Sensory evaluation techniques (4th Edition ed.). Boca Raton, Florida: CRC Press. 2007.

26. Eletta OAA, Orimolade BO, Oluwaniyi OO, Dosumu OO. Evaluation of proximate and antioxidant activities of Ethiopian eggplant (Solanum aethiopicum $\mathrm{L}$ ) and gboma eggplant (Solanum macrocarpon L). J App/ Sci Environ Manag. 2017;21(5):967-972. doi: 10.4314/ jasem.v21i5.25

27. Agoreyo BO, Obansa ES, Obanor EO. Comparative nutritional and phytochemical analyses of two varieties of Solanum melongena. Science World Journal. 2012;7(1):5-8. https://www.ajol.info/index. $\mathrm{php} / \mathrm{swj} /$ article/view/82252

28. Odetola AA, Iranloye YO, Akinloye O. Hypolipidaemic potentials of Solanum melongena and Solanum gilo on hypercholesterolemic rabbits. Pak J Nutr. 2004;3(3):180-187. doi: 10.3923/pjn.2004.180.187

29. Showemimo FA, Olarewaju JD. Agro nutritional determinants of some garden varieties (Solanum gilo L.). J Food Technol. 2004;2(3):172175. https://medwelljournals.com/ abstract/?doi=jftech.2004.172.175

30. Edijala JK, Asagba SO, Eriyamremu GE, Atomatofa U. Comparative effect of garden egg fruit, oat and apple on serum lipid profile in rats fed a high cholesterol diet. Pak J Nutr. 2005;4(4):245-249. doi: 10.3923/ pjn.2005.245.249

31. Bonsu KO, Fontem DA, Nkansah GO, Iroume RN, Owusu EO, Schippers RR. Diversity within the gboma eggplant (Solanum macrocarpon), an indigenous vegetable from West Africa. Ghana Journal of Horticulture. 2002;1:5058.

32. Naeem MY, Ugur S. Nutritional content and health benefits of eggplant. Turkish J Agric - Food Sci Technol. 2019;7(sp3):31-36. doi: 10.24925/turjaf. v7isp3.31-36.3146

33. Fraikue FB. Unveiling the potential utility of eggplant: a review. Conference Proceedings of INCEDI. 2016;883895.

34. Edem C, Dosunmu MI, Bassey FI, Wilson C, Umoren P. A comparative assessment of the proximate composition, ascorbic acid and heavy metal content of two species of garden egg (Solanum gilo and Solanum aubergine). Pak J Nutrition. 2009;8(5):582-584. doi: 10.3923/pjn.2009.582.584

35. Mukisa IM, Byaruhanga YB, Muyanja CMBK, Langsrud $T$, Narvhus JA. Production of organic flavor compounds by dominant lactic acid bacteria and yeasts from Obushera, a traditional sorghum malt fermented beverage. Food Sci Nutr. 2017;5(3):702-712. doi: 10.1002/fsn3.450

36. Behera SS, Ray RC, Zdolec N. Lactobacillus plantarum with functional properties: An approach to increase safety and shelf-life of fermented foods. BioMed Research International. 2018;2018:9361614. doi: $10.1155 / 2018 / 9361614$

37. El Sheikha AF, Hu DM. Molecular techniques reveal more secrets of fermented foods. Critical Reviews in Food Sci Nutr. 2020;60(1):11-32. doi:

\subsection{0/10408398.2018.1506906}

38. Casado FJ, Lopez A, Rejano L, Sanchez AH, Montano A. Nutritional composition of commercial pickled garlic. Eur Food Res Technol. 2004;219(4):355-359. doi: 10.1007/s00217-004-1003-5

39. Arivalagan M, Bhardwaj R, Gangopadhyay KK, Prasad TV, Sarkar SK. Mineral composition and their genetic variability analysis in eggplant (Solanum melongena L.) germplasm. Journal of Applied Botany and Food Quality. 2013;86(1):99-103. doi: 10.5073/ JABFQ.2013.086.014

40. Kortei NK, Suetor JM, Aboagye G, Tettey CO, Kpodo FM, Essuman EK. Comparative study of the bioactive and chemical properties of three different Solanum spp. from Ghana. Food Research. 2020;4(5):1773-1784. doi: 10.26656/fr.2017.4(5).010

41. Agyei-Poku B. The Effect of pre-treatment and oven drying temperatures on the nutritional, antinutritional values and colour properties of the fruits of Solanum torvum. Ghana: Kwame Nkrumah University of Science and Technology, PhD thesis. 2018.

42. Brewer GJ, Wallimann TW. Protective effect of the energy precursor creatine against toxicity of glutamate and $\beta$-amyloid in rat hippocampal neurons. J Neurochem. 2000;74(5):1968-1978. doi: 10.1046/ j.1471- 4159.2000.0741968.x

43. Cassidy A, Mukamal KJ, Liu L, Franz M, Eliassen AH, Rimm EB. High anthocyanin intake is associated with a reduced risk of myocardial infarction in young and middleaged women. Circulation. 2013;127(2):188-196. doi: 10.1161/circulationaha.112.122408

44. Li X, Ning Y, Liu D, et al. Metabolic mechanism of phenyllactic acid naturally occurring in Chinese pickles. Food Chem. 2015;186:265-270. doi: 10.1016/j. foodchem.2015.01.145

45. Lavermicocca P, Valerio F, Evidente A, Lazzaroni $S$, Corsetti A, Gobbetti M. Purification and characterization of novel antifungal compounds from the sour dough Lactobacillus plantarum strain 21B. Appl Environ Microbiol. 2000;66(9):4084-4090. doi: 10.1128/aem.66.9.4084-4090.2000

46. Valerio F, Lavermicocca P, Pascale M, Visconti A. Production of phenyllactic acid by lactic acid bacteria: An approach to the selection of strains contributing to food quality and preservation. FEMS Microbiol Lett. 2004;233(2):289-295. doi: 10.1016/j. femsle.2004.02.020

47. Zaro MJ, Keunchkarian S, Chaves AR, Vicente AR, Concellon A. Changes in bioactive compounds and response to postharvest storage conditions in purple eggplants as affected by fruit developmental stage. Posharvest Biology Technology. 2014;96:110-117. doi: 10.1016/j.postharvbio.2014.05.012

48. Kharat MM, Adiani V, Variyar P, Sharma A, Singhal RS. Antioxidant compounds in traditional Indian pickles may prevent the process induced formation of benzene. J Food Protect. 2016;79(1):123-131. doi: 10.4315/0362-028x.jfp-15-218

49. Ozdal T, Capanoglu E, Altay F. A review on proteinphenolic interactions and associated changes. Food Res Int. 2013;51(2):954-970. doi: 10.1016/j. foodres.2013.02.009 
50. Shahidi F, Naczk M. Phenolics in Food and Nutraceuticals. CRC Press, Boca Raton, FL. 2004. doi: 10.1201/9780203508732

51. Sugiyama $\mathrm{H}$, Akazome $\mathrm{Y}$, Shoji $\mathrm{T}$, et al. Oligomeric procyanidins in apple polyphenol are main active components for inhibition of pancreatic lipase and triglyceride absorption. J Agric Food Chem. 2007;55(11):4604-4609. doi: 10.1021/jf070569k

52. Arimboor R, Arumughan C. Sea buckthorn (Hippophae rhamnoides) proanthocyanidins inhibit in vitro enzymatic hydrolysis of protein. J Food Sci. 2011;76(6):130-137. doi: 10.1111/j.17503841.2011.02238.x

53. Goncalves R, Mateus N, Defreitas V. Inhibition of $\alpha$-amylase activity by condensed tannins. Food Chem. 2011;125(2):665-672. doi: 10.1016/j. foodchem.2010.09.061

54. Dixon RA, Xie D, Sharma SB. Proanthocyanidins - a final frontier in flavonoid research? New Phytologist. 2005;165(1):9-28. doi: 10.1111/j.14698137.2004.01217.x

55. Gu L, House SE, Rooney L, Prior RL. Sorghum bran in the diet dose dependently increased the excretion of catechins and microbial-derived phenolic acids in female rats. J Agric Food Chem. 2007;55(13):53265334. doi: 10.1021/jf070100p

56. Ou K, Gu L. Absorption and metabolism of proanthocyanidins. J Funct Foods. 2014;7:43-53. doi: 10.1016/j.jff.2013.08.004

57. Angel R, Tamim NM, Applegate TJ, Dhandu AS, Ellestad LE. Phytic acid chemistry: influence on phytin-phosphorus availability and phytase efficacy. J Appl Poult Res. 2002;11(4):471-480. doi: 10.1093/ japr/11.4.471

58. Rickard SE, Thompson LU. Interactions and biological effects of phytic acid. In: Shahidi F, editor. Antinutrients and Phytochemical in Food. ACS Publication, Washington, DC; 1997:294-312. doi: 10.1021/bk1997-0662.ch017

59. Schlemmer U, Frolich W, Prieto RM, Grases F. Phytate in foods and significance for humans: food sources, intake, processing, bioavailability, protective role and analysis. Mol Nutr Food Res. 2009;53(S2):330-375. doi: 10.1002/mnfr.200900099

60. Schlemmer U, Jany K, Berk A, Schulz E, Rechkemmer G. Degradation of phytate in the gut of pigspathway of gastrointestinal inositol phosphate hydrolysis and enzymes involved. Archives of Animal Nutrition. 2001;55(4):255-280. doi: 10.1080/17450390109386197

61. Duhan A, Chauhan BM, Punia D, Kapoor AC. Phytic acid content of chickpea (Cicer arietinum) and black gram (Vigna mungo): varietal differences and effect of domestic processing and cooking methods. J Sci Food Agric. 1989;49(4):449-455. doi: 10.1002/ jsfa. 2740490407

62. Sathe SK, Venkatachalam M. Influence of processing technologies on phytate and its removal. In Food Phytates. CRC Press, Boca Raton; 2002:157-188. doi: 10.1201/9781420014419.ch10

63. Diana L, HsinI W, Wan-Jen W, Ray-Yu Y. Anti-nutrient components and their concentrations in edible parts in vegetable families. CAB Reviews. 2018;13:015. doi: 10.1079/PAVSNNR201813015

64. Hatch M, Freel RW. Intestinal transport of an obdurate anion: oxalate. Urological Research. 2005;33(1):1-16. doi: 10.1007/s00240-004-0445-3

65. Hughes J, Norman RW. Diet and calcium stones. Canadian Medical Association Journal. 1992;146(2):137.

66. Noonan SC, Savage GP. Oxalate content of foods and its effect on humans. Asia Pac J Clin Nutr. 1999;8(1):64-74. doi: 10.1046/j.1440-6047.1999.00038.x

67. Marengo SR, Romani AMP. Oxalate in renal stone disease: the terminal metabolite that just won't go away. Nat Clin Pract Nepro. 2008;4(7):368-377. doi: 10.1038/ncpneph0845

68. Oke MO, Bolarinwa IF. Effect of fermentation on physicochemical properties and oxalate content of cocoyam (Colocasia esculenta) flour. ISRN Agronomy. 2012;2012:978709. doi: 10.5402/2012/978709

69. Gadd GM, Bahri-Esfahani J, Li Q, et al. Oxalate production by fungi: significance in geomycology, biodeterioration and bioremediation. Fungal Biology Reviews. 2014;28(2-3):36-55. doi: 10.1016/j. fbr.2014.05.001

70. Olajide R, Akinsoyinu AO, Babayemi OJ, Omojola AB, Abu AO, Afolabi KD. Effect of processing on energy values, nutrient and anti-nutrient components of wild cocoyam (Colocasia esculenta (L.) Schott) corm. Pak J Nutr. 2011;10(1):29-34. doi: 10.3923/pjn.2011.29.34

71. Patel K, Singh RB, Patel DK. Medicinal significance, pharmacological activities, and analytical aspects of solasodine: a concise report of current scientific literature. Journal of Acute Disease. 2013;2(2):92-98. doi: 10.1016/S2221-6189(13)60106-7

72. Kanika P, Vikas K, Dinesh KP. An update of therapeutic potential and bioanalytical aspects of steroidal glycoalkaloid (solanidine). Journal of Coastal Life Medicine. 2017;5(3):134-140. doi: 10.12980/ jclm.5.2017J6-256

73. Roddick JG, Rijnenberg AL. Synergistic interaction between the potato glycoalkaloids $\alpha$-solanine and $\alpha$-chaconine in relation to lysis of phospholipid/sterol liposomes. Phytochemistry. 1987;26:1325-1328.

74. Bello SO, Muhammad BY, Gammaniel KS, et al. Preliminary evaluation of the toxicity and some pharmacological properties of the aqueous crude extract of Solanum melongena. Res J Agric Biol Sci. 2005;1(1):1-9.

75. Cao G, Sofic E, Prior RL. Antioxidant capacity of tea and common vegetables. J Agri Food Chem. 1996;44:34263431. doi: 10.1021/jf9602535

76. Bagchi $M$, Milnes $M$, Williams $C$, et al. Acute and chronic stress-induced oxidative gastrointestinal injury in rats and the protective ability of a novel grape seed proanthocyanidin extract. Nutr Res. 1999;19(8):11891199. doi: 10.1016/S0271-5317(99)00080-9

77. Hanson PM, Yang RY, Tsou SCS, Ledesma D, Engle L, Lee TC. Diversity on eggplant (Solanum melongena) for superoxide scavenging activity, total phenolics, and ascorbic acid. Journal of Food Composition and Analysis. 2006;19(6-7):594-600. doi: 10.1016/j. jfca.2006.03.001 
78. Sudheesh S, Presannakumar G, Vijayakumar S, Vijayalakshmi NR. Hypolipidemic effect of flavonoids from Solanum melongena. Plant Foods Hum Nutr. 1997;51:321-330. doi: 10.1023/A:1007965927434

79. Guimaraes PR, Galvao AMP, Batista CM, et al. Eggplant (Solanum melongena) infusion has a modest and transitory effect on hypercholesterolemic subjects. Braz J Med Biol Res. 2000;33(9):1027-1036. doi: 10.1590/S0100-879X2000000900006

80. Toor RK, Savage GP. Antioxidant activity in different fractions of tomatoes. Food Rese Int. 2005;38(5):487494. doi: $10.1016 / \mathrm{j}$.foodres.2004.10.016

81. Ginwala R, Bhavsar R, Chigbu DGI, Jain P, Khan ZK. Potential role of flavonoids in treating chronic inflammatory diseases with a special focus on the anti-inflammatory activity of apigenin. Antioxidants. 2019;8(2): 35. doi: 10.3390/antiox8020035

82. Tettey CO, Ocloo A, Nagajyothi PCN, Lee KD. An in vitro analysis of antiproliferative and antimicrobial activities of solvent fractions of Taraxacum officinale (Dandelion) leaf. Journal of Applied Pharmaceutical Sciences. 2014;4(3):041-045. doi: 10.7324/ JAPS.2014.40309

83. Gomez-Ordonez E, Jimenez-Escrig A, Ruperez P. Effect of the red seaweed Mastocarpus stellatus intake on lipid metabolism and antioxidant status in healthy Wistar rats. Food chem. 2012;135(2):806-811. doi: 10.1016/ j.foodchem.2012.04.138

84. Swain MR, Anandharaj M, Ray RC, Rani RP. Fermented fruits and vegetables of Asia: A potential source of probiotics. Biotechnol Res Int. 2014;2014:250424. doi: 10.1155/2014/250424

85. LeBlanc JG, Milani C, de Giori GS, Sesma F, van Sinderen D, Ventura M. Bacteria as vitamin suppliers to their host: A gut microbiota perspective. Curr Opin Biotechnol. 2013;24(2):160-168. doi: 10.1016/j. copbio.2012.08.005

86. Rajesh N, Imelda-Joseph, Raj RP. Value addition of vegetable wastes by solid-state fermentation using Aspergillus niger for use in aquafeed industry. Waste Management. 2010;30(11):2223-2227. doi: 10.1016/j. wasman.2009.12.017

87. Almeida JA, Mussi LP, Oliveira DB, Pereira NR. Effect of temperature and sucrose concentration on the retention of polyphenol compounds and antioxidant activity of osmotically dehydrated bananas. Journal of Food Processing and Preservation. 2015;39(6):10611069. doi: 10.1111/jfpp.12321

88. Shalaby EA, Mahmoud GI, Shanab SMM. Suggested mechanism for the effect of sweeteners on radical scavenging activity of phenolic compounds in black and green tea. Frontiers in Life Science. 2016;9(4):241-251. doi: 10.1080/21553769.2016.1233909

89. Sayin FK, Alkan SB. The effect of pickling on total phenolic contents and antioxidant capacities of 10 vegetables. Journal of Food and Health Science. 2015;1(3):135-141. doi: 10.3153/JFHS15013

90. Maruvada R, McFeeters RF. Evaluation of enzymatic and non-enzymatic softening in low salt cucumber fermentations. Int J Food Sci Technol. 2009;44(6):11081117. doi: 10.1111/j.1365-2621.2009.01925.x

91. Cetin B. Production of probiotic mixed pickles (Tursu) and microbiological properties. African J Biotechnol. 2011;10(66):14926-14931. doi: 10.5897/AJB11.2621

92. Nout MJR. Fermented foods and food safety. Food Res Int. 1994;27(3):291-298. doi: 10.1016/09639969(94)90097-3

93. Irkin R, Songun GE. Applications of probiotic bacteria to the vegetable pickle products. Sci Revs Chem Commun. 2012;2(4):562-567.

94. Leroy F, Vuyst LD. Lactic acid bacteria as functional starter cultures for the food fermentation industry. Trends in Food Science and Technology. 2004;15(2):6778. doi: 10.1016/j.tifs.2003.09.004

95. Ragul K, Syiem I, Sundar K, Shetty PH. Characterization of probiotic potential of Bacillus species isolated from a traditional brine pickle. J Food Sci Technol. 2017;54(13):4473-4483. doi: 10.1007/s13197-0172928-6

96. Bhowmik T, Marth EH. Role of Micrococcus and Pediococcus species in cheese ripening: A review. J Dairy Sci. 1990;73:859-866. doi: 10.3168/jds.S00220302(90)78740-1

97. Kazemipoor M, Radzi CWJWM, Begum K, Yaze I. Screening of antibacterial activity of lactic acid bacteria isolated from fermented vegetables against food borne pathogens. Archives des Sciences. 2012;65(6):192-201. https://arxiv.org/ftp/arxiv/papers/1206/1206.6366. pdf

98. Tamang JP, Watanabe K, Holzapfel WH. Review: Diversity of microorganisms in global fermented foods and beverages. Front Microbiol. 2016;7:377. doi: 10.3389/fmicb.2016.00377

99. Joshi VK, Sharma S. A Panorama of lactic acid bacterial fermentation of vegetables. International Journal of Food and Fermentation Technology. 2012;2: 1-12. https://www.indianjournals.com/ijor. aspx?target=ijor:ijft \&volume $=2 \&$ issue $=1 \&$ article $=001$ 